\title{
Effect of post-emergence herbicides on yield of Kharif groundnut
}

\author{
P.V. Mahatale*, M.Y. Ladole, E.R. Vaidaya and S.N. Deshmukh
}

\begin{abstract}
A field experiment was conducted to investigate the most appropriate post emergence herbicides for the maximum weed control and yield enhancement in groundnut (Arachis hypogaea L.). The experiment in a RCBD with three replicates was conducted during Kharif season (June to October) 2013 and 2014 at the Oilseeds Research Unit, Dr. Panjabrao Deshmukh Krishi Vidyapeeth, Akola (M.S.), India. The crop variety AK 159 was sown at a spacing of $30 \mathrm{~cm}$ (between rows) x $10 \mathrm{~cm}$ (within row). Nine treatments including six postemergence herbicides applied at 2-4 leaf stage of weeds, a pre-emergence herbicide, and a weedy and weed-free (hand weeding) control. The recommended mixture of fertilizer 25:50 $\mathrm{N}$, and $\mathrm{P}(\mathrm{kg} / \mathrm{ha})$ was applied as a basal dressing using Urea $(46 \% \mathrm{~N})$ and SSP $\left(16 \% \mathrm{P}_{2} \mathrm{O}_{5}\right)$, respectively. Among the herbicidal treatments, the lowest weed index (3.26\%) was observed under post-emergence herbicides Propaquizafop $10 \mathrm{EC}(100 \mathrm{~g} / \mathrm{ha})$ followed Quizalofop ethyl 5 EC (100 g/ha) with a weed index of $9.74 \%$. The minimum weed dry weight was also recorded in these treatments, which was significantly lower $(p<0.05)$ than all other treatments. The lowest weed control efficiency (81.6\%) was recorded in plots with the pre-emergence application of Pendimethalin 30 EC (1000 g/ha). The highest dry pods yield (2,927 kg/ha) was recorded in the weed free control (hand weeding 20 and 40 Days after emergence) and the lowest $(1,520 \mathrm{~kg} / \mathrm{ha})$ was under un-weeded control. The post-emergence herbicides Propaquizafop $10 \mathrm{EC}$ (100 g/ha) recorded the highest gross and net monetary returns, which were at par ( $p>0.05)$ with Quizalofop ethyl 5 EC (100 g/ha) but significantly higher $(p<0.05)$ as compared to other herbicidal treatments. Application of post--herbicides effectively controlled weeds, and resulted in a considerably lower cost of cultivation compared with hand weeding. The benefit:cost ratio was the highest with post emergence herbicides Propaquizafop 10 EC (100 g/ha) followed by Quizalofop ethyl 5 EC (100 g/ha) compared to other treatments.
\end{abstract}

Keywords: Groundnut yield, post emergence herbicides, weed control

\section{Introduction}

Groundnut (Arachis hypogaea L.) is grown mainly in the Kharif season (June-October) in India. It encounters severe weed infestation especially in the early stages of growth, as the crop seedling emerges seven to ten days after sowing coupled with the slow growth in the initial stages. The weeds emerge faster and grow rapidly competing with the crop severely for the resources namely, nutrients, light, and space and also transpire conserved water from the soil. On an average, the loss of groundnut production in the country due to weeds has been estimated as $33-70 \%$ (Dotray et al., 2012). Thus, weed control during initial stage of crop growth is

Oilseeds Research Unit, Dr. Panjabrao Deshmukh Krishi Vidyapeeth Akola (M.S.), India

* Corresponding author: mahatale1978@rediffmail.com 
essential to achieve the optimum crop yield. Though, physical methods of weed control are effective, the non-availability of labor during peak growing period, high labor cost, and unfavorable environmental conditions such as rainfall are among the major limitations in achieving successful results. Under such conditions, the chemical weed control plays an important role in groundnut and substantially enhances the crop yield (Patil et al., 2012). Hence, an experiment was designed to elucidate the success of weed management in groundnut with the use of several post-emergence herbicides.

\section{Materials and Methods}

A field experiment was conducted during Kharif (June to October) season in 2013 and 2014 at the Oilseeds Research Unit, Dr. Panjabrao Deshmukh Krishi Vidyapeeth, Akola (M.S.) in India. Groundnut (Arachis hypogeae L.) variety AK 159 was sown at a spacing of $30 \mathrm{~cm}$ (between rows) $\times 10 \mathrm{~cm}$ (within row) in a randomized complete block design (RCBD) with three replicates having nine treatments namely, $\mathrm{T}_{1}$ : Weeded check (un-weeded), $\mathrm{T}_{2}$ : Weed-free check (Clean plot), $\mathrm{T}_{3}$ : Propaquizafop 10 EC (100 g a.i./ha), $\mathrm{T}_{4}$ : Quizalofop ethyl 5 EC (50 g a.i./ha), $\mathrm{T}_{5}$ : Quizalofop ethyl 5 EC (100 g a.i./ha), $\mathrm{T}_{6}$ : Imazethapyr 10\% SL (50 g a.i./ha), $\mathrm{T}_{7}$ : Imazethapyr 10\% SL (100 g a.i./ha), $\mathrm{T}_{8}$ : Imazethapyr+Imazamox 70\% WG (100 g a.i./ha) and $\mathrm{T}_{9}$ : Pendimethalin 30 EC (1000 g a.i./ha). The treatments $T_{3}-T_{8}$ were post-emergence herbicides applied at 25-30 days after crop emergence (DACE), where the weeds were at 2-4 leaf stage. The $T_{9}$ is a pre-emergence herbicide. Hand weeding (control, $T_{2}$ ) was done at fortnightly intervals until crop harvest. The herbicides were sprayed using a knapsack sprayer fitted with a flat fan nozzle, with spray volume of $500 \mathrm{~L} / \mathrm{ha}$. The gross and net plot sizes were $3.6 \mathrm{~m} \times 3 \mathrm{~m}$ and $3 \mathrm{~m} \times 2.8 \mathrm{~m}$, respectively. The recommended fertilizer $25: 50 \mathrm{~N}: \mathrm{P}$ was used as a basal dressing using Urea $(46 \% \mathrm{~N})$ and SSP $\left(16 \% \mathrm{P}_{2} \mathrm{O}_{5}\right)$, respectively.

The weed index (WI \%), weed control efficiency \% (visual observation compared to the weedy check) and weed dry weight $/ \mathrm{m}^{2}$ were determined at 60 days after weed emergence. The dry pod yield and haulm yield were obtained at harvest. The N (Kjeldhal method), P (Olsen-P) and K (Flame photometric method) uptake of weeds and crop were measured at the time of harvest. The gross monetary return (GMR, Indian Rs/ha), net monetary return (NMR; Indian Rs/ha), cost of cultivation (Indian Rs/ha) and the benefit:cost ratio of the treatments were calculated. Data of the two experiments were pooled for statistical analysis. Mean separation was done using critical difference at $\mathrm{p}=0.05$.

\section{Results and Discussion}

The weeds observed in experiment site are given in Table 1. The experimental plots were dominated by broadleaf weeds followed by grasses. 
Table 1. Weeds observed in the experimental site

\begin{tabular}{|c|c|c|}
\hline \multirow{2}{*}{ Weed species } & Common name & Family \\
\hline & \multicolumn{2}{|c|}{ Grasses } \\
\hline Cynodon dactylon (L.) Pers. & Doob grass & Poaceae \\
\hline Ischaemum pilosum (Klein ex Willd.) & Kunda grass & Poaceae \\
\hline Digitaria sanguinalis (L.) Scop. & Crab grass & Poaceae \\
\hline \multirow[t]{2}{*}{ Panicum spp. } & Fall panicum & Poaceae \\
\hline & \multicolumn{2}{|c|}{ Broadleaf weeds } \\
\hline Achyranthus aspera Linn. & Prickly chaff flower & Amaranthaceae \\
\hline Celosia argentia Linn. & Cock comb & Amaranthaceae \\
\hline Commelina benghalensis $\mathrm{L}$. & Day flower & Commelianaceae \\
\hline Convolvulus arvensis L. & Bind weed & Convolvulaceae \\
\hline Digera arvensis Forssk. & Amaranthus & Amaranthaceae \\
\hline Euphorbia hirta L. & Spurge & Euphorbiaceae \\
\hline Euphorbia geniculate Ortega. & Spurge & Euphorbiaceae \\
\hline Parthenium hysterophorus L. & Rag weed & Compositeae \\
\hline Phyllanthus niruri L. & Niruri & Euphorbiaceae \\
\hline \multirow[t]{2}{*}{ Tridax procumbens L. } & Tridex & Compositeae \\
\hline & \multicolumn{2}{|c|}{ Sedges } \\
\hline Cyperus rotundus L. & Nut sedge & Cyperaceae \\
\hline
\end{tabular}

All herbicidal treatments significantly influenced $(\mathrm{p}<0.05)$ the weed index $(\mathrm{Wl})$ dry matter production of weeds (Table 2). The lowest WI (3.26\%) was observed in the plots treated with Propaquizafop 10 EC (100 g a.i./ha) followed by $(f b)$ Quizalofop ethyl 5 EC (100 g a.i./ha). The post-emergence application of Imazethapyr 10\% SL (100 g a.i./ha), Imazethapyr+Imazamox 70\% WG (100 g a.l./ha) and Quizalofop ethyl 5 EC (50 g a.i./ha), and the pre-emergence application of Pendimethalin $30 \mathrm{EC}$ (1000 g a.i./ha) and the un-weeded check showed similar WIs ( $p>0.05)$ and were significantly higher $(p<0.05)$ over the rest of the treatments. The maximum weed control efficiency (96.4\%) was recorded with the post-emergence application of Propaquizafop 10 EC (100 g a.i./ha) fb Quizalofop ethyl 5 EC (100 g a.i./ha), Imazethapyr 10\% SL (100 g a.i./ha), Imazethapyr+Imazamox 70\% WG (100 g a.i./ha) and Quizalofop ethyl 5 EC (50 g a.i./ha). The lowest weed control efficiency was recorded with the pre-emergence application of Pendimethalin 30 EC (1000 g a.i./ha).

The lowest weed density and weed dry weight were recorded in the weedfree plots. Among the herbicidal treatments, Propaquizafop 10 EC (100 g a.i./ha) recorded the lowest weed density and dry weight $(p<0.05)$ than the other herbicidal treatments. The plots with pre-emergence application of Pendimethalin 30 EC (1000 $g$ a.i./ha) and the un-weeded check showed similar ( $p>0.05)$ but higher weed densities $(p<0.05)$ over the rest. These results are in conformity with the findings of Patil et al. (2012) and Attarde et al. (2001) suggesting that the herbicides used have longer effect on weed controlling with significant reduction in weed dry matter as compared to un-weeded check. 
Table 2. Weed growth, yield and economics of Kharif groundnut as influenced by different weed control treatments

\begin{tabular}{|c|c|c|c|c|c|c|c|c|c|c|}
\hline Treatments $^{1}$ & $\begin{array}{c}\text { Weed } \\
\text { Index } \\
(\%)\end{array}$ & $\begin{array}{c}\text { Weed } \\
\text { control } \\
\text { efficiency } \\
(\%)\end{array}$ & $\begin{array}{c}\text { Weed } \\
\text { density } \\
\left(\text { No. } / \mathrm{m}^{2}\right)\end{array}$ & $\begin{array}{l}\text { Weed } \\
\text { dry } \\
\text { matter } \\
\left(\mathrm{g} / \mathrm{m}^{2}\right)\end{array}$ & $\begin{array}{l}\text { Dry pod } \\
\text { yield } \\
\text { (kg/ha) }\end{array}$ & $\begin{array}{c}\text { Haulm } \\
\text { yield } \\
\text { (kg/ha) }\end{array}$ & $\begin{array}{l}\mathrm{GMR}^{2} \\
(\mathrm{Rs} / \mathrm{ha})\end{array}$ & $\begin{array}{c}\operatorname{coc}^{3} \\
\text { (Rs/ha) }\end{array}$ & $\begin{array}{l}\mathrm{NMR}^{4} \\
\text { (Rs/ha) }\end{array}$ & $\begin{array}{l}\mathrm{B}: \mathrm{C}^{5} \\
\text { Ratio }\end{array}$ \\
\hline $\mathrm{T}_{1}$ : Un-weeded check (control) & 48.1 & 0.0 & 132.4 & 914.6 & 1520 & 3129 & 48640 & 24738 & 23902 & 1.97 \\
\hline $\mathrm{T}_{2}:$ Weed-free check & 0.0 & 100.0 & 1.0 & 1.00 & 2927 & 3919 & 93674 & 32513 & 61161 & 2.88 \\
\hline $\begin{array}{l}\mathrm{T}_{3}: \text { Propaquizafop } 10 \text { EC (100 g a.i./ha), } \\
\text { post-emergence }\end{array}$ & $3 \cdot 3$ & 96.4 & $9 \cdot 9$ & 46.5 & 2832 & 3543 & 90624 & 27814 & 62810 & 3.26 \\
\hline $\begin{array}{l}\mathrm{T}_{4}: \text { Quizalofop ethyl } 5 \text { EC (50 g a.i./ha), } \\
\text { post-emergence }\end{array}$ & 17.1 & 87.3 & 14.2 & 70.5 & 2444 & 3297 & 78192 & 27325 & 50867 & 2.86 \\
\hline $\begin{array}{l}\mathrm{T}_{5}: \text { Quizalofop ethyl } 5 \text { EC (100 g } \\
\text { a.i./ha), post-emergence }\end{array}$ & 9.7 & 94.6 & 11.9 & 56.5 & 2689 & 3377 & 86048 & 27728 & 58320 & 3.10 \\
\hline $\begin{array}{l}\mathrm{T}_{6} \text { : Imazethapyr } 10 \% \text { SL (50 g a.i./ha), } \\
\text { post-emergence }\end{array}$ & 14.2 & 89.8 & 34.0 & 170.7 & 2546 & 3351 & 81472 & 27413 & 54059 & 2.97 \\
\hline $\begin{array}{l}\mathrm{T}_{7}: \text { Imazethapyr } 10 \% \mathrm{SL} \text { (100 g a.i./ha), } \\
\text { post-emergence }\end{array}$ & 12.8 & 92.6 & 26.3 & 131.2 & 2603 & 3471 & 83285 & 27884 & 55401 & 2.99 \\
\hline $\begin{array}{l}\mathrm{T}_{8} \text { : Imazethapyr+Imazamox 70\% WG } \\
\text { (100 g a.i./ha), post-emergence }\end{array}$ & 16.9 & 88.3 & $39 \cdot 3$ & 198.9 & 2486 & 3223 & 79552 & 27568 & 51984 & 2.89 \\
\hline $\begin{array}{l}\mathrm{T}_{9}: \text { Pendimethalin } 30 \mathrm{EC}(1000 \mathrm{~g} \\
\text { a.i./ha), pre-emergence }\end{array}$ & 31.6 & 81.6 & 85.1 & 578.9 & 2141 & 3154 & 68522 & 27542 & 40980 & 2.49 \\
\hline $\mathrm{SE}(\mathrm{m})^{6}$ & 2.38 & 3.84 & 9.28 & 34.9 & 103 & 185 & 26523 & & & \\
\hline$C D^{7}$ at $p=0.05$ & 7.03 & 11.34 & 28.09 & 105.4 & 311 & 558 & 79934 & & & \\
\hline Grand Mean & 17.07 & 81.17 & $39 \cdot 35$ & 240.9 & 2465.3 & 3384.8 & 78889 & 27836 & 51053 & 2.82 \\
\hline
\end{tabular}

1 = Rates of herbicides are expressed as the amount of active ingredient (a.i.); 2 = gross monetary ratio in Indian Rs; $3=$ net monetary ratio in Indian Rs.; 4 = cost of cultivation in Indian Rs.; 5 = benefit:cost ratio; 6 = standard error of the means; 7 = critical difference 
The weed-free check recorded the highest dry pod yield of groundnut $(2927 \mathrm{~kg} / \mathrm{ha})$ followed by ( $p>0.05)$ post-emergence application of Propaquizafop 10 EC (100 g a.i./ha) and Quizalofop ethyl 5 EC (100 g a.i./ha), but significantly higher $(p<0.05)$ compared to the rest of the herbicide treatments (Table 2). The un-weeded check recorded the lowest pod yield $(1520 \mathrm{~kg} / \mathrm{ha})$. The results are similar to those reported by Malunjkar et al. (2006), Sukhadia et al. (1998) and Virender et al. (2009). Walia et al. (2007) also reported yield losses in groundnut due to uncontrolled weed growth. Chaitanya et al. (2013) reported that the pre-emergence application of Pendimethalin (1000 g a.i./ha) along with Quizalofop ethyl (50 g a.i./ha) applied at 25 DACE has resulted in a higher growth and yield of Kharif groundnut compared to the farmerpractice and other weed management practices.

Among the herbicidal treatments, Propaquizafop $10 \mathrm{EC}$ (100 g a.i.//ha) recorded the maximum GMR and NMR, which was in par ( $p>0.05$ ) with Quizalofop ethyl 5 EC (100 g a.i./ha), but significantly higher $(p<0.05)$ compared to other treatments. The results supported the findings of Fayyaz and Azhar (2000), Majumder et al. (2009) and Malligawad et al. (2000). Herbicidal treatments incurred a lesser cost compared to hand weeding. The $\mathrm{B}: \mathrm{C}$ ratio was the highest with Propaquizafop $10 \mathrm{EC}$ (100 g a.i./ha) followed by Quizalofop ethyl 5 EC (100 g a.i./ha) than the rest of the treatments. Ghose et al. (2000) reported that the critical period for weed competition of the groundnut crop is during the first 50 to 60 days. In the preset study, weed competition during the first 30 days period of groundnut crop growth was found critical under Kharif rainfed condition.

Nutrient uptake by groundnut was higher in the weed-free treatment (Table 3), followed by post-emergence application of Propaquizafop 10 EC (100 g a.i./ha).

Table 3. Uptake of N, P and K by weeds ( $\mathrm{kg} / \mathrm{ha}$ ) at crop harvest as influenced by various weed control treatments

\begin{tabular}{|c|c|c|c|}
\hline \multirow{2}{*}{ Treatments $^{1}$} & $\mathrm{~N}$ & $\mathrm{P}$ & K \\
\hline & \multicolumn{3}{|c|}{$(\mathrm{kg} / \mathrm{ha})$} \\
\hline $\mathrm{T}_{1}:$ Un-weeded check (control) & 53.90 & 25.6 & 39.50 \\
\hline $\mathrm{T}_{2}:$ Weed-free check & 0.00 & 0.00 & 0.00 \\
\hline $\mathrm{T}_{3}:$ Propaquizafop $10 \mathrm{EC}$ (100 g a.i./ha), post-emergence & $14 \cdot 57$ & 12.2 & 16.15 \\
\hline $\mathrm{T}_{4}:$ Quizalofop ethyl 5 EC (50 g a.i./ha), post-emergence & 14.81 & 12.4 & 14.00 \\
\hline $\mathrm{T}_{5}$ : Quizalofop ethyl $5 \mathrm{EC}$ (100 g a.i./ha), post-emergence & 12.79 & 3.70 & 5.47 \\
\hline $\mathrm{T}_{6}:$ Imazethapyr $10 \% \mathrm{SL}$ (50 g a.i./ha), post-emergence & 13.82 & 11.1 & 11.82 \\
\hline $\mathrm{T}_{7}:$ Imazethapyr 10\% SL (100 g a.i./ha), post-emergence & 12.83 & 7.9 & 8.56 \\
\hline $\mathrm{T}_{8}$ : Imazethapyr+Imazamox 70\% WG (100 g a.i./ha), post-emergence & 14.10 & 11.8 & 12.64 \\
\hline $\mathrm{T}_{9}:$ Pendimethalin $30 \mathrm{EC}$ (1000 g a.i./ha), pre-emergence & 18.34 & $14 \cdot 3$ & 18.71 \\
\hline S.E. $(m)^{2}$ & 1.19 & 0.7 & 0.94 \\
\hline C.D. ${ }^{3}$ at $p=0.05$ & 3.57 & 2.1 & 2.84 \\
\hline Grand mean & 17.24 & 11.0 & 14.09 \\
\hline
\end{tabular}

$1=$ Rates of herbicides are expressed as the amount of active ingredient (a.i.); 2 = standard error of the means; 3 = critical difference 
Weeds in the un-weeded control showed a significantly higher $(p<0.05)$ nutrient uptake compared to the rest due to higher weed density in the former. Among the herbicidal treatment, post-emergence application of Quizalofop ethyl 5 EC (100 g a.i./ha) also produced better weed control and thus higher nutrient uptake by groundnut crop (Table 4) as reported by Dixit et al. (2012). The available N, P and K in soil would have been higher in the weed-free treatment thus resulting in higher crop uptake followed by the post-emergence application of Propaquizafop 10 EC (100 g a.i./ha) as observed by Chaitanya et al. (2013).

Table 4. Uptake of N, P and K by groundnut (kg/ha) at harvest as influenced by various weed control treatments

\begin{tabular}{lccc}
\hline \multirow{2}{*}{ Treatments } & $\mathrm{N}$ & $\mathrm{P}$ & $\mathrm{K}$ \\
\cline { 2 - 4 } & \multicolumn{3}{c}{$(\mathrm{kg} / \mathrm{ha})$} \\
\hline $\mathrm{T}_{1}$ : Un-weeded check (control) & 95.69 & 11.31 & 46.20 \\
$\mathrm{~T}_{2}$ : Weed-free check & 195.27 & 34.03 & 112.53 \\
$\mathrm{~T}_{3}$ : Propaquizafop 10 EC (100 g a.i./ha), post-emergence & 179.20 & 30.90 & 97.10 \\
$\mathrm{~T}_{4}$ : Quizalofop ethyl 5 EC (50 g a.i./ha), post-emergence & 146.50 & 16.60 & 67.00 \\
$\mathrm{~T}_{5}$ : Quizalofop ethyl 5 EC (100 g a.i./ha), post-emergence & 161.71 & 25.90 & 76.99 \\
$\mathrm{~T}_{6}$ : Imazethapyr 10\% SL (50 g a.i.//ha), post-emergence & 148.69 & 20.37 & 75.39 \\
$\mathrm{~T}_{7}:$ Imazethapyr 10\% SL (100 g a.i./ha), post-emergence & 151.60 & 22.63 & 76.21 \\
$\mathrm{~T}_{8}:$ Imazethapyr+Imazamox 70\% WG (100 g a.i./ha), post-emergence & 140.89 & 18.47 & 69.82 \\
$\mathrm{~T}_{9}:$ Pendimethalin 30 EC (1000 g a.i./ha), pre-emergence & 123.04 & 14.73 & 61.45 \\
S.E. (m) & 9.83 & 1.16 & 5.16 \\
C.D. 3 at p=0.05 & 29.64 & 3.48 & 15.56 \\
Grand mean & 149.17 & 21.66 & 75.85 \\
\hline
\end{tabular}

$1=$ Rates of herbicides are expressed as the amount of active ingredient (a.i.); 2 = standard error of the means; 3 = critical difference

\section{Conclusion}

Post-emergence application of Propaquizafop $10 \mathrm{EC}$ (100 g a.i./ha) and Quizalofop ethyl 5 EC (100 g a.i./ha), were most effective for controlling weeds, and found to be profitable through improvement productivity of Kharif groundnut.

\section{Acknowledgement}

Authors are thankful to the Oilseeds Research Unit, Dr. Panjabrao Deshmukh Krishi Vidyapeeth at Akola, India for providing necessary facilities to conduct the study.

\section{References}

Attarde, D.R., Surya Waanshi, R.T. and Wadile, S.C. (2001): Integrated weed management in kharif groundnut under assured rainfed conditions. J. Maha. Agric. Univ., 26(2): 161-163. 
Chaitanya, S., Shankaranarayana, V. and Nanjappa, H.V. (2013): Influence of different herbicides on growth and yield of kharif groundnut. Mysore J. Agric. Sci., 47(2): 214218.

Dixit, J.P. Singh, H. and Bhadauria, S.K.S. (2012): Quizalofop ethyl an effective post emergence herbicide to control grassy weeds of groundnut, Annals Plant and Soil Res., 14(1): 2224.

Dotray, P.A. Grichar, W.J. Baughman, T.A., Prostko, E.P., Grey, T.L. and Gilbert, L.V. (2012): Peanut (Arachis hypogaea L.) response to lactofen at various post emergence timings. Peanut Sci., 39(1): 9-14.

Fayyaz M.C. and Azhar A.A. (2000): Effect of pre-emergence herbicides on nodulation, nitrogen fixation and morphological characters in groundnut (Arachis hypogea L.) Pak. J. Biol. Sci., 3(10): 1775-1777.

Majumder, A., Sahu, A.K., Karan, A.K, Kundu, C.K. Nath, R. and Bera, P.S. (2009): Critical period of weed control in summer ground in gangetic alluvial region in West Bengal. J. Crop and Weed, 5(1), 246-250.

Malligawad, L.H. Kannur, V. S. and Giriraj, K. (2000): Integrated weed control in kharif groundnut. Karnataka J. Agric. Sci., 13(2): 288-294.

Malunjkar, B.D. Mulik, B.B. and Patil, S.C. (2006): Evaluation of post-emergence herbicides in rainy season groundnut. Ind. J. Weed Sci., 44(2): 95-97.

Patil, Y.R., Bhale, V.M. and Karmore, J.V. (2012 ): Integrated weed management in groundnut (Arachis hypogeal L.) Bhartiya Krishi Anushandhan Patrika, 27(2): 76-80.

Sukhadia, N.M, Ramani, B.B., Asodaria, K.B. and Modhwadia, M.M. (1998): Comparative efficacy of pre and post emergence herbicide application in spreading groundnut. Ind. J. Weed Sci., 30(3-4): 163-167.

Virender S. and Parvender, S. (2009): Efficacy of herbicides against weeds in groundnut, (Arachis hypogaea L)., J. Oilseeds Res., 26(1): 55-58.

Walia, U.S., Singh, S. and Singh, B. (2007): Integrated approach for the control of hardy weeds in groundnut (Arachis hypogaea L.). Ind. J. Weed Sci., 39(1-2): 112-115. 
Mahatale et al. 